\title{
Front Matter: Volume 10553
}

, "Front Matter: Volume 10553," Proc. SPIE 10553, Novel In-Plane Semiconductor Lasers XVII, 1055301 (23 March 2018); doi: $10.1117 / 12.2323053$

SPIE. Event: SPIE OPTO, 2018, San Francisco, California, United States 


\title{
PROCEEDINGS OF SPIE
}

\section{Novel In-Plane Semiconductor Lasers XVII}

\author{
Alexey A. Belyanin \\ Peter M. Smowton \\ Editors
}

29 January - 1 February 2018

San Francisco, California, United States

Sponsored and Published by

SPIE 
The papers in this volume were part of the technical conference cited on the cover and title page. Papers were selected and subject to review by the editors and conference program committee. Some conference presentations may not be available for publication. Additional papers and presentation recordings may be available online in the SPIE Digital Library at SPIEDigitalLibrary.org.

The papers reflect the work and thoughts of the authors and are published herein as submitted. The publisher is not responsible for the validity of the information or for any outcomes resulting from reliance thereon.

Please use the following format to cite material from these proceedings:

Author(s), "Title of Paper," in Novel In-Plane Semiconductor Lasers XVII, edited by Alexey A. Belyanin, Peter M. Smowton, Proceedings of SPIE Vol. 10553 (SPIE, Bellingham, WA, 2018) Seven-digit Article CID Number.

ISSN: 0277-786X

ISSN: 1996-756X (electronic)

ISBN: 9781510615915

ISBN: 9781510615922 (electronic)

Published by

SPIE

P.O. Box 10, Bellingham, Washington 98227-0010 USA

Telephone +1 3606763290 (Pacific Time) · Fax +1 3606471445

SPIE.org

Copyright (C) 2018, Society of Photo-Optical Instrumentation Engineers.

Copying of material in this book for internal or personal use, or for the internal or personal use of specific clients, beyond the fair use provisions granted by the U.S. Copyright Law is authorized by SPIE subject to payment of copying fees. The Transactional Reporting Service base fee for this volume is $\$ 18.00$ per article (or portion thereof), which should be paid directly to the Copyright Clearance Center (CCC), 222 Rosewood Drive, Danvers, MA 01923. Payment may also be made electronically through CCC Online at copyright.com. Other copying for republication, resale, advertising or promotion, or any form of systematic or multiple reproduction of any material in this book is prohibited except with permission in writing from the publisher. The CCC fee code is 0277$786 \mathrm{X} / 18 / \$ 18.00$.

Printed in the United States of America.

Publication of record for individual papers is online in the SPIE Digital Library.

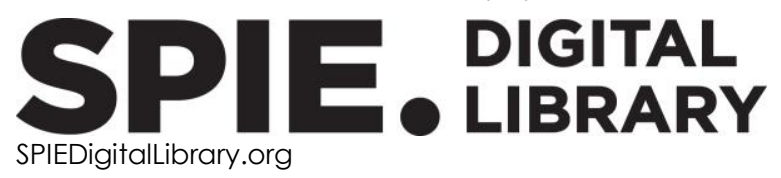

Paper Numbering: Proceedings of SPIE follow an e-First publication model. A unique citation identifier (CID) number is assigned to each article at the time of publication. Utilization of CIDs allows articles to be fully citable as soon as they are published online, and connects the same identifier to all online and print versions of the publication. SPIE uses a seven-digit CID article numbering system structured as follows:

- The first five digits correspond to the SPIE volume number.

- The last two digits indicate publication order within the volume using a Base 36 numbering system employing both numerals and letters. These two-number sets start with $00,01,02,03,04$, 05, 06, 07, 08, 09, OA, OB ... 0Z, followed by 10-1Z, 20-2Z, etc. The CID Number appears on each page of the manuscript. 


\title{
Contents
}

\author{
vii Authors \\ ix Conference Committee
}

\section{PLENARY SESSION}

1055302 III-nitride nanowire LEDs and diode lasers: monolithic light sources on (001) Si emitting in the 600-1300nm range (Plenary Paper) [10553-202]

\section{DEVELOPING LASER MATERIALS}

1055307 Laser diodes using InAIGaAs multiple quantum wells intermixed to varying extent [10553-56]

\section{NITRIDES/VISIBLE EMITTING LASERS}

1055308 Defect evolution during catastrophic optical damage in 450nm emitting InGaN/GaN diode lasers (Invited Paper) [10553-5]

10553 OA 10th order laterally coupled GaN-based DFB laser diodes with v-shaped surface gratings (Invited Paper) [10553-7]

\section{ANTIMONIDE-BASED MID-IR LASERS}

10553 OC New GasB based single mode diode lasers in the NIR and MIR spectral regime for sensor applications [10553-9]

10553 OE Magneto-optical properties of potassium terbium fluoride [10553-1 1]

\section{QUANTUM DOT LASERS}

10553 OG Incorporating structural analysis in a quantum dot Monte-Carlo model [10553-13]

$105530 \mathrm{~J} T$ Temperature dependence of spectral linewidth of InAs/InP quantum dot distributed feedback lasers [10553-16]

\section{TEMPORAL EFFECTS AND MODE LOCKED LASERS}

10553 OK Pico- and nanosecond investigations of the lateral nearfield of broad area lasers under pulsed high-current excitation [10553-17] 
10553 OL Spontaneous generation of frequency combs in QD lasers [10553-18]

10553 OM Influence of different approaches for dynamical performance optimization of monolithic passive colliding-pulse mode-locked laser diodes emitting around 850 nm [10553-19]

10553 ON Passive, active, and hybrid mode-locking in a self-optimized ultrafast diode laser [10553-20]

1055300 High pulse energy stabilized passively mode-locked external cavity inverse bow-tie 980nm laser diode for space applications [10553-21]

MID-IR QCLS AND ICLS

10553 OP Continuous wave power scaling in high power broad area quantum cascade lasers [10553-22]

$105530 Q \quad 3.35 \mu \mathrm{m}$ distributed feedback interband cascade lasers with top grating [10553-23]

\section{PHOTONIC BANDGAP AND CAVITY EFFECTS}

1055310 Reflectors and tuning elements for widely-tunable GaAs-based sampled grating DBR lasers [10553-33]

\section{COMBS AND MODE LOCKING}

1055319 Passive mode-locking of $3.25 \mu \mathrm{m}$ GaSb-based type-I quantum-well cascade diode lasers [10553-42]

\section{HIGH POWER/BRIGHTNESS}

$105531 \mathrm{C}$ Diffraction limited 1064nm monolithic DBR-master oscillator power amplifier with more than 7W output power [10553-45]

10553 ID Comparison of distributed Bragg reflector ridge waveguide diode lasers and monolithic master oscillator power amplifiers [10553-46]

10553 IF $\quad 5.5 \mathrm{~nm}$ wavelength tunable high power MOPA diode laser system at $971 \mathrm{~nm}$ [10553-48]

$105531 \mathrm{G}$ Comparison for 1030nm DBR tapered diode lasers with 10W central lobe output power and different grating layouts for wavelength stabilization and lateral spatial mode filtering [10553-49] 
POSTER SESSION

10553 IL Angled facet waveguide quantum cascade laser for external cavity system [10553-54]

$105531 \mathrm{M}$ Stability of the mode-locking regime in tapered quantum-dot lasers [10553-55]

Proc. of SPIE Vol. $105531055301-5$

Downloaded From: https://www.spiedigitallibrary.org/conference-proceedings-of-spie on 26 Apr 2023 Terms of Use: https://www.spiedigitallibrary.org/terms-of-use 
Proc. of SPIE Vol. 10553 1055301-6

Downloaded From: https://www.spiedigitallibrary.org/conference-proceedings-of-spie on 26 Apr 2023 Terms of Use: https://www.spiedigitallibrary.org/terms-of-use 


\section{Authors}

Numbers in the index correspond to the last two digits of the seven-digit citation identifier (CID) article numbering system used in Proceedings of SPIE. The first five digits reflect the volume number. Base 36 numbering is employed for the last two digits and indicates the order of articles within the volume. Numbers start with 00, 01, 02, 03, 04, 05, 06, 07, 08, 09, OA, OB...0Z, followed by 10-1Z, 20-2Z, etc.

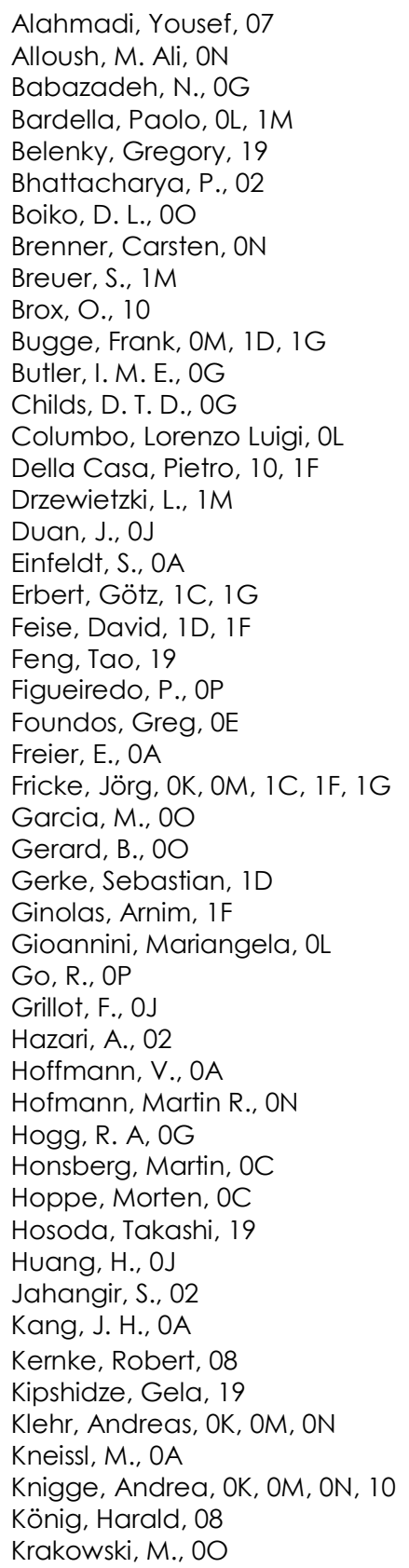

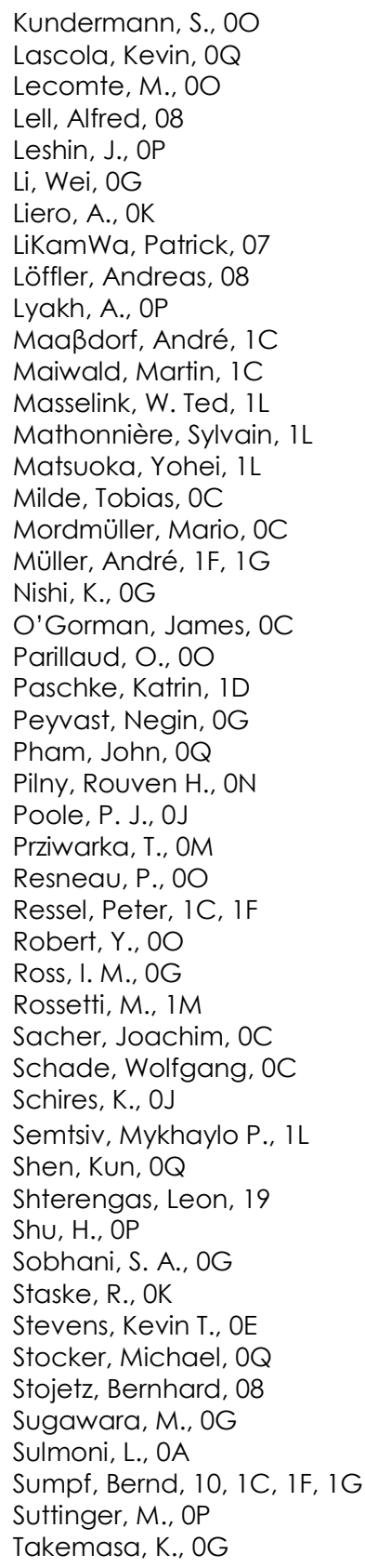


Tatenguem, Herve, $\mathrm{OC}$

Tawfieq, Mahmoud, 10, 1F

Tomm, Jens W., 08

Torcheboeuf, N., 00

Towner, Frederick, OQ

Tränkle, Günther, 0M, 0N, 1C, 1D, 1F, 1G

Unger, R.-S., OA

Vinet, E., 00

Wang, C., OJ

Wang, Jie, $O Q$

Wang, Meng, 19

Weber, C., $1 \mathrm{M}$

Wegemund, Jan, 1D

Wenzel, H., OA, OK, OM, 10

Werner, Nils, ID

Wernicke, T., OA

Weyers, M., OM, 10

Xie, Feng, $O Q$

Zeghuzi, A., OK

Zelmon, David E., OE

Zink, Christof, 1C, 1G 


\title{
Conference Committee
}

\author{
Symposium Chairs
}

Connie J. Chang-Hasnain, University of California, Berkeley (United States)

Graham T. Reed, Optoelectronics Research Centre, University of Southampton (United Kingdom)

Symposium Co-Chairs

Jean-Emmanuel Broquin, IMEP-LAHC (France)

Shibin Jiang, AdValue Photonics, Inc. (United States)

Program Track Chair

Klaus P. Streubel, OSRAM AG (Germany)

Conference Chairs

Alexey A. Belyanin, Texas A\&M University (United States)

Peter M. Smowton, Cardiff University (United Kingdom)

Conference Program Committee

Yasuhiko Arakawa, The University of Tokyo (Japan)

Mikhail A. Belkin, The University of Texas at Austin (United States)

Dan Botez, University of Wisconsin-Madison (United States)

Federico Capasso, Harvard School of Engineering and Applied Sciences (United States)

Gary A. Evans, Southern Methodist University (United States)

Michael Kneissl, Technische Universität Berlin (Germany)

Luke F. Lester, Virginia Polytechnic Institute and State University (United States)

Shinji Matsuo, NTT Photonics Laboratories (Japan)

Luke J. Mawst, University of Wisconsin-Madison (United States)

Jerry R. Meyer, U.S. Naval Research Laboratory (United States)

Roberto Paiella, Boston University (United States)

Richard V. Penty, University of Cambridge (United Kingdom)

Johann Peter Reithmaier, Universität Kassel (Germany)

Haisheng Rong, Intel Corporation (United States)

Gary M. Smith, MIT Lincoln Laboratory (United States)

Nelson Tansu, Lehigh University (United States)

Miriam Serena Vitiello, Consiglio Nazionale delle Ricerche (Italy) 
Qi Jie Wang, Nanyang Technological University (Singapore)

\section{Session Chairs}

1 Developing Laser Materials

Luke J. Mawst, University of Wisconsin-Madison (United States)

2 Nitrides/Visible Emitting Lasers

Michael Kneissl, Technische Universität Berlin (Germany)

3 Antimonide-based Mid-IR Lasers

Leon Shterengas, Stony Brook University (United States)

4 Quantum Dot Lasers

Peter M. Smowton, Cardiff University (United Kingdom)

5 Temporal Effects and Mode Locked Lasers

Johann Peter Reithmaier, Universität Kassel (Germany)

$6 \quad$ Mid-IR QCLs and ICLS

Gerard Wysocki, Princeton University (United States)

7 QCLs for Spectroscopy

Feng Xie, Thorlabs Quantum Electronics (United States)

8 Photonic Bandgap and Cavity Effects

Alexey A. Belyanin, Texas A\&M University (United States)

9 QCL Frequency Combs

Sukhdeep Dhillon, Laboratoire Pierre Aigrain (France)

10 Combs and Ultrafast Modulation

Marco Piccardo, Harvard John A. Paulson School of Engineering and Applied Sciences (United States)

11 Combs and Mode Locking

Karl Unterrainer, Technische Universität Wien (Austria)

12 High Power/Brightness

Gary M. Smith, MIT Lincoln Laboratory (United States)

$13 \mathrm{THz}$ QCLS

Maria Catrina Giordano, CNR-NANO (Italy) 